\title{
Property of the HPHT Diamonds Using Stack Cell and Zn Coating with Pressure
}

\author{
Yun Shen and Ohsung Song ${ }^{\dagger}$
}

Department of Materials Science and Engineering, University of Seoul, Seoul 130-743, Korea

(Received December 19, 2011; Revised January 17, 2012; Accepted January 18, 2012)

\section{적층형 셀과 아연도금층을 이용한 고온고압 합성다이아몬드의 압력변화에 따른 물성 연구}

\author{
신 운 · 송오성 \\ 서울시립대학교 신소재공학과 \\ (2011년 12월 19일 접수 ; 2012년 1월 17일 수정 ; 2012년 1월 18일 채택)
}

\begin{abstract}
Fine diamond powders are synthesized with a $420 \phi$ cubic press and stack-cell composed of $\operatorname{Kovar}\left(\mathrm{Fe}_{54} \mathrm{Ni}_{29} \mathrm{Co}_{17}\right)$ (or Kovar $+7 \mu \mathrm{m}$ thick $\mathrm{Zn}$ electroplated) alloy and graphite disks. The high pressure high temperature (HPHT) process condition was executed at $1500^{\circ} \mathrm{C}$ for 280 seconds by varying the nominal pressure of $5.7 \sim 10.6 \mathrm{GPa}$. The density of formation, size, shape, and phase of diamonds are determined by optical microscopy, field emission scanning electron microscopy, thermal gravimetric analysis-differential thermal ammnlysis (TGA-DTA), X-ray diffraction (XRD), and micro-Raman spectroscopy. Through the microscopy analyses, we found that $1.5 \mu \mathrm{m}$ super-fine tetrahedral diamonds were synthesized for $\mathrm{Zn}$ coated Kovar cell with whole range of pressure while $\sim 3 \mu \mathrm{m}$ superfine diamond for conventional Kovar cell with $<10.6 \mathrm{GPa}$. Based on $750^{\circ} \mathrm{C}$ exothermic reaction of diamonds in TGA-DTA, and characteristic peaks of the diamonds in XRD and micro-Raman analysis, we could confirm that the diamonds were successfully formed with the whole pressure range in this research. Finally, we propose a new process for super-fine diamonds by lowering the pressure condition and employing $\mathrm{Zn}$ electroplated Kovar disks.
\end{abstract}

Keywords : HPHT, Super fine diamond, Kovar, Zn, Stack-cell

\section{1. 서 론}

현재 공업용 합성 다이아몬드의 세계시장 규모는 약 6 억 달러이고, 합성 다이아몬드로 만든 공구까지 포함하면 60 억 달러에 이른다. 공업용 다이아몬드는 각종 기계류의 정밀 가공의 기본 연마제로써 사용되며 그 외 고강도 소재 의 절삭재료, 가공재로로 활용되어 전략소재로서의 가치가 점점 중요해지고 있다. ${ }^{1)}$

합성다이아몬드는 기존의 기간산업 분야용도 외에도 최 근에는 인쇄회로기판( $\mathrm{PCB})$, 발광다이오드(LED), 태양광산 업용 기판 등 정밀 소재 가공 수요가 늘어나면서 정밀전 자, 반도체 분야의 활용도 크게 늘고 있다. 특히 반도체 가공용 다이아몬드는 반도체 웨이퍼 연마와 평탄화 공정 에 사용되므로 형상과 크기가 일정한 초미세다이아몬드

\footnotetext{
${ }^{\dagger}$ Corresponding author : Ohsung Song

E-mail : songos@uos.ac.kr

Tel : +82-2-2210-2604 Fax : +82-2-2215-5863
}

이어야 한다.

합성 다이아몬드는 일반적으로 입도가 $104 \mu \mathrm{m}$ 보다 작 은 것을 공업용 분말형 다이아몬드라고 하고, 이중 특히 $38 \mu \mathrm{m}$ 보다 작은 것을 초미세 다이아몬드라고 분류한다. 이런 초미세 다이아몬드는 합성속도가 빠르고 핵생성과 우선성장 현상으로 컨트롤이 매우 어려운 문제가 있고 제 조 후에 응집효과 때문에 분리 또한 매우 어려우므로 상 대적으로 부가가치가 높은 특징이 있다. 초미세다이아몬 드는 반도체 산업의 성장과 함께 시장규모가 매년 $20 \%$ 이 상씩 성장할 것으로 예상되고, 가격도 일반 공업용 다이아 몬드 가격의 8 10배 수준을 유지할 것으로 예상된다. ${ }^{2-4)}$

일반적으로 분말형 합성다이아몬드는 고온고압공정을 이용하여 제조된다. 1955년 $\mathrm{GE}$ 가 일축프레스를 합성다이 아몬드의 제조에 성공한 후 분말형 다이아몬드는 비약적 인 초고압프레스분야의 기술개발에 따라 고수율 생산이 진행되고 있다. 특히 최근의 중국의 육방정프레스는 안정 적으로 압력과 온도를 유지하고 공정제어가 간단한 장점 을 가지고 있어서 활용이 늘고 있다. 
이러한 고온고압법으로 초미세 다이아몬드를 제조하기 위해서는, 기존 연구에 의하면 크게 분쇄법과 제삼원소 첨가법, 그리고 화학기상증착법을 이용한 합성방법이 가 능하다.

먼저 분쇄법은 기존의 고온고압 공정으로 만들어진 분 말형 다이아몬드를 분쇄하는 방법으로 가장 현재 보편적 으로 사용되고 있는 방법이다. 그러나 이렇게 만들어진 초미세 다이아몬드들은 모양과 입도가 균일하지 않아 분 급이 어려운 문제점을 가지고 있다. ${ }^{5)}$

첨가법은 기존의 고온고압공정인 금속촉매와 흑연분말 을 혼합하는 과정에서 다이아몬드가 금속촉매에서 석출 성장하는 것을 방해할 수 있는 제 3 의 첨가원소를 혼합하 여 제조하는 방법이다. $\mathrm{Gao}$ 는 $\mathrm{Zn}$ 분말을 첨가제로 사용 하여 $10 \mu \mathrm{m}$ 급의 초미세 입자의 공업용 다이아몬드를 성 공적으로 합성을 하였다. ${ }^{5}$ 그러나 이러한 제3원소를 첨가 하는 방법은 재료의 혼합을 위한 시편 준비 시간이 길고 금속분말의 표면적이 커서 산화를 방지하여야 하는 등 공 정이 복잡해지는 단점이 있다.

그 외 화학기상증착법은 $900^{\circ} \mathrm{C}$ 이상의 고온에서 탄소 를 함유한 메탄가스와 수소가스를 환원제로 하여 미세 다 이아몬드를 실리콘과 같은 단결정 기판에 증착한 후 분 리하는 방법이다. 그러나 화학기상증착법은 한정된 반응 로에 다이아몬드를 배치공정으로 생산해 하고 초미세 분 말의 분리공정이 어려우므로 제조 원가가 비싸다는 단점 을 가지고 있다. ${ }^{6}$

따라서 본 연구는 새롭게 금속촉매 또는 $\mathrm{Zn}$ 도금된 촉 매와 흑연디스크를 차례로 적층한 적층형 셀과 육방정프 레스 시스템을 채용하여 $\mathrm{Zn}$ 도금층의 유무와 압력조건 변화에 따라 합성된 다이아몬드의 물성 변화를 확인해 보 았다.

\section{2. 실험 방법}

고온고압 환경을 만들어 다이아몬드를 성장시키기 위 하여 Guilin사의 $420 \Phi$ HPHT 육방정프레스 장비와 적층 형 셀을 이용하여 분말형 다이아몬드를 제조하였다. 육방 정프레스는 $38 \mathrm{~mm}$ 의 정육면체 셀에 $20 \mathrm{GPa}, 2000^{\circ} \mathrm{C}$ 까지 압력과 온도를 가할 수 있도록 육방정프레스 본체와 유 압펌프 시스템, 컨트롤러로 구성되었다. 정육면체의 적층 형 셀을 여섯 방향에서 균일하게 가압하여 정수압을 가 하도록 설계되었다.

적층형 셀은 Fig. 1과 같이 정육면체의 파이로필라이트 개스킷(gasket)에 직경 $20 \mu \mathrm{m}$ 의 반응부를 가지며 반응부 상부에는 각 6 개의 탄소디스크와 Kovar 금속촉매디스크 6 개를 서로 교차시켜 적층시키고, 하부에는 6개의 탄소디 스크와 6 개의 $7 \mu \mathrm{m}$ 두께의 $\mathrm{Zn}$ 를 표면에 전기 도금한 Kovar 금속촉매 디스크를 서로 교차시켜 적층시켜서 상 하부의 고온고압 공정 시 동시에 동일 압력과 온도조건

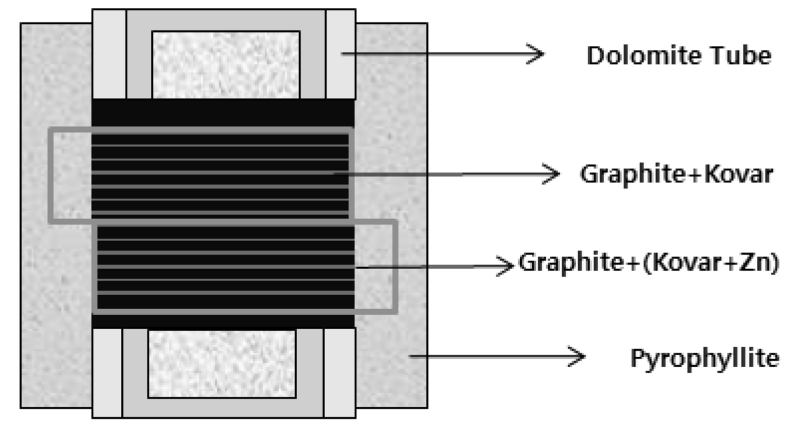

Fig. 1. A schematic illustration of the stack type cell.

에서 두 가지 시료를 얻을 수 있도록 하였다. 양전극부에 는 탄소디스크를 3 개씩 적층하여 구성하였다. 이때 Kovar 금속촉매는 $\mathrm{Fe}, \mathrm{Ni}, \mathrm{Co}$ 의 조성이 각각 $54: 29: 17$ 인 합금 을 말한다.

고온고압 공정조건은 적층형 셀 안의 온도가 $1500^{\circ} \mathrm{C}$ 되 게 한 후 $280 \mathrm{sec}$ 간 동일한 조건에서 압력을 각각 5.7, 6.0, $6.6,7.1,7.5,10.6 \mathrm{GPa}$ 로 변화시키면서 다이아몬드가 생성 되도록 실험을 진행하였다.

공정이 완료된 각 적층형 셀은 파괴시켜 합성된 분말 형 합성다이아몬드의 아연도금 유무에 따라 상하부를 분 리하여 각 부분을 왕수용액(aqua-regia)에 담가 금속부분 만을 선택적으로 제거하였다. 남은 흑연과 다이아몬드 분 말덩어리는 다시 $98 \%$ 황산에서 일부 흑연을 제거시켜 다 이아몬드 분말시료를 준비하였다. ${ }^{7)}$

압력변화에 따른 분말다이아몬드의 확대이미지와 밀도 를 분석하기 위하여 시편의 위쪽 방향에서 백색광원을 조사하여 광학현미경(Calzeiss, DE/Stemi DR1663)을 이용 하여 관찰하였고, 이를 접안렌즈에 연결된 디지털카메라 (ZEISS, Axio Cam ICc1)를 이용하여 200 배율로 촬영하 였다.

다이아몬드의 모양과 사이즈 분포를 확인하기 위해서 FE-SEM(field emission scanning electron microscope, Hitachi S4300)을 이용하여 금속촉매디스크를 분리하여 표 면에 대한 미세구조를 관찰하였다. $15 \mathrm{kV}$ 가속전압을 사 용하여 5000배의 배율까지 관찰하였다.

준비된 다이아몬드 분말과 흑연분말의 혼합시료에서 흑 연만을 선택적으로 제거하는 최적온도를 확인하기 위해 TGA-DTA 열분석기(TA Instruments Q2000)를 이용하였다. 온도가 증가함에 따라 혼합시료의 탄소성분이 산소와 반 응하여 $\mathrm{CO}_{2}$ 로 산화되면서 질량과 열량의 급격한 변화가 일어나는 최적온도를 알아보기 위해 온도 상승속도를 $20^{\circ} \mathrm{C} / \mathrm{min}$ 로 하여 $100 \sim 900^{\circ} \mathrm{C}$ 온도범위에서 열중량분석 (TGA)과 시차열분석(DTA)을 병행하면서 측정하였다.

적층형셀을 이용하여 합성된 초미세 다이아몬드의 생 성된 상을 확인하기 위해서 고분해능 $\mathrm{X}$-선 회절분석(XRD, PANalytical사, X'pert-pro)을 이용하였다. X선 소스는 니 
켈 필터를 통과시켜 얻는 $\mathrm{CuKa}$ 로 파장은 $1.5402 \AA$ 이며, 전류는 $30 \mathrm{~mA}$, 가속전압은 $40 \mathrm{kV}$ 이었다. 회절범위는 JCPDS (joint committee power diffraction standards) 카 드에 나타나 있는 다이아몬드와 흑연을 고려하여 $2 \theta$ 값 을 $20^{\circ} \sim 70^{\circ}$ 범위에서 탄소의 결정성을 조사하였다. 시편 은 적층형셀에서 분리된 흑연층과 금속촉매층의 표면부 를 모두 확인하였다.

또한 UniThink사의 라만분광기 (Raman spectroscopy, UniRaman)을 이용하여 금속디스크부분에 대해 분석하여 다이아몬드의 생성을 확인하였다. 시편은 고온고압 합성 공정 후 적층형 셀에서 분리된 금속촉매층의 표면을 가 시영역의 레이저로 입사하여 산란된 빛 파장의 주파수를 측정하여 성분분석을 진행하였다. 이때 DPSS laser의 광 원은 $532 \mathrm{~nm}$ 유지하며 Back-illuminated $\mathrm{CCD}$ 를 검출기로 이용하여 노출 시간을 $5 \mathrm{sec}$ 로 하여 광범위 영역을 측정하 였다. 특히 다이아몬드의 경우 $1332 \mathrm{~cm}^{-1}$, 흑연인 경우 $1350 \mathrm{~cm}^{-1}, 1600 \mathrm{~cm}^{-1}$ 에서 각각 라만특성 피크가 나오는 것으로 알려져 있으므로 이로써 다이아몬드와 기타 흑연 및 카본계 잔류물을 정성적으로 분석하였다. ${ }^{8,9)}$

\section{3. 결과 및 고찰}

Fig. 2는 압력을 각각 5.7, $10.6 \mathrm{GPa}$ 로 변화시킨 후의 적 층형 셀에 탄소디스크의 중심부에 대한 광학현미경 이미 지이다. (a), (b)는 일반 Kovar 금속촉매층을 사용한 경우이 고 (c), (d)는 $7 \mu \mathrm{m}$ 의 $\mathrm{Zn}$ 를 Kovar 금속촉매층에 전기 도금 한 경우이다. (a), (c)는 $5.7 \mathrm{GPa}$ 에, (b), (d)는 $10.6 \mathrm{GPa}$ 조건 에서 $\mathrm{HPHT}$ 성장된 생성된 경우이다. 그림 모두 하얀점으 로 보이는 점이 다이아몬드 입자들이라고 판단하였다. 따 라서 전체 압력범위에서 $\mathrm{Zn}$ 의 코팅유무에 관계없이 모두 다이아몬드가 생성되었음을 확인하였다. 또한 광학현미경 이미지의 컨트라스트를 조절하여 $677 \times 415 \mu \mathrm{m}^{2}$ 의 면적 의 다이아몬드의 갯수를 측정하여 다이아몬드의 생성량 을 확인하였다. 각 압력별로, $\mathrm{Zn}$ 도금 유무에 따른 합성 다이아몬드의 양을 Fig. 3에 나타내었다. 다이아몬드의 생 성유무는 후에 기술할 TGA-DTA, XRD, 마이크로라만분 석으로 재차 확인하였다.

Fig. 3은 Fig. 2에서 찍은 광학현미경 이미지들로부터 결 정된 단위면적당 생성된 다이아몬드의 갯수를 압력에 따 라 나타내었다. ' $\square$ ' 부분은 일반 Kovar 촉매인 경우이고, ' $\square$ ' 은 금속촉매에 $\mathrm{Zn}$ 을 코팅된 경우이다. $\mathrm{Zn}$ 의 코팅 유 무와 관계없이 압력이 $6.7 \mathrm{GPa}$ 를 중심으로 이보다 압력이 증가하면 생성밀도가 감소하고 이보다 압력이 작으면 다 이아몬드 생성밀도가 감소하는 추이를 보였다. 이는 핵생 성과 성장 기구에 의해 생성되는 다이아몬드가 압력이 작 으면 다이아몬드 안정구간이 열역학적으로 줄어들기 때 문에 핵생성한 후 성장되지 못하여 일부 핵이 소멸되기

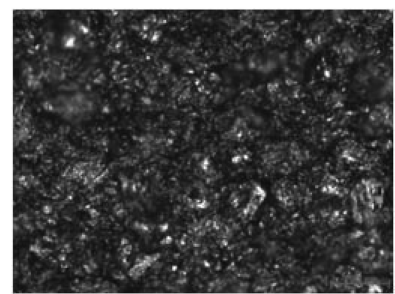

(a)

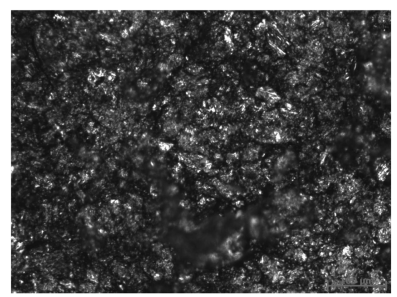

(c)

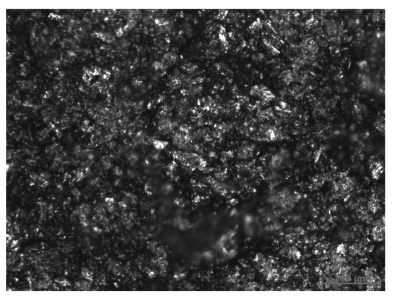

(b)

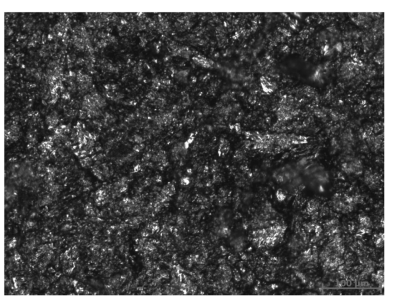

(d)
Fig. 2. Optical micrographs of the diamonds and graphite mixtures with Zn coating (c, d): prepared at (a)(b) 5.7 $\mathrm{GPa}$, and (c)(d) $10.6 \mathrm{GPa}$.

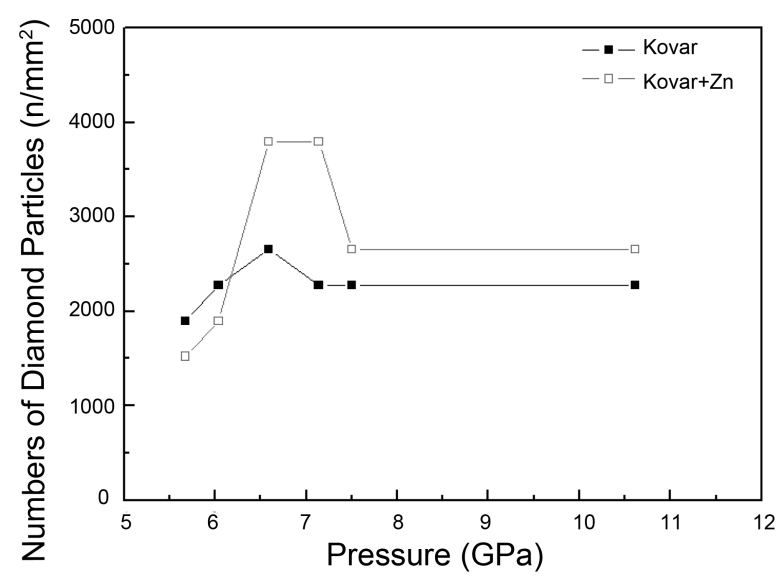

Fig. 3. A plot of the number of diamond particles with pressure.

때문이고, 압력이 너무 크면 핵이 성장하다가 주위의 핵 과 병합되면서 유효한 성장 개수가 상대적으로 감소하기 때문에 다이아몬드 생성 개수를 증가시키려면 특정한 최 적 압력조건이 있는 것으로 판단되었다.

Fig. 4는 공정 압력을 각각 5.7, $10.6 \mathrm{GPa}$ 로 변화시키면 서 제조된 탄소와 다이아몬드 혼합분말에서의 다이아몬 드 입자의 주사전자현미경 이미지이다.

(a), (b)는 일반 Kovar 금속촉매층을 사용한 경우이고, (c), (d)는 $\mathrm{Zn}$ 가 금속촉매층에 코팅된 경우이다. (a), (c)는 $5.7 \mathrm{GPa}$ 에, (b), (d)는 $10.6 \mathrm{GPa}$ 조건에서 합성된 다이아몬 드의 이미지이다. 중앙부의 흰색으로 보이는 입자가 전자 빔의 차징효과 때문에 밝게 보이는 부도체인 다이아몬드 이고 이러한 이미지로부터 각 압력조건에서 형성된 다이 아몬드의 형상과 크기를 확인하였다. 배율이 다른 (b)를 보면 대부분 사면체입자인 경우와 달리 14 면체의 평균직 


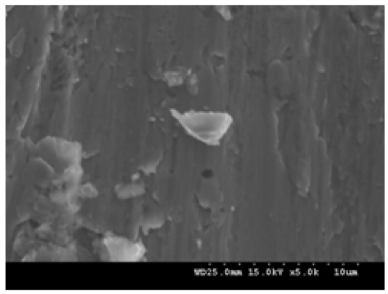

(a)

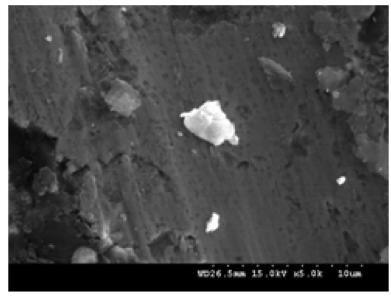

(c)

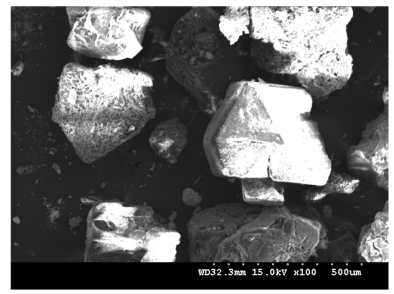

(b)

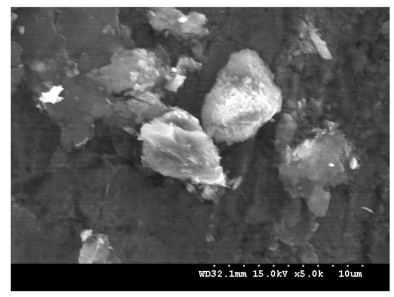

(d)
Fig. 4. The SEM images of the diamond particles with Kovar (a)(b), and Kovar $+\mathrm{Zn}$ coating (c)(d): prepared at 5.7 $\mathrm{GPa}(\mathrm{a})(\mathrm{c})$, and 10.6 GPa (b)(d).

\section{경 $520 \mu \mathrm{m}$ 의 다이아몬드가 형성되었음을 확인하였다.}

Fig. 5는 Fig. 4의 결과를 바탕으로 각 조건에서의 평균 다이아몬드 크기와 형상을 나타낸 그린 그래프이다. 먼저 $\square$ 로 표현한 $\mathrm{Zn}$ 를 코팅한 금속촉매를 사용하면 전체 실 험압력 범위에서 모두 $2 \mu \mathrm{m}$ 이하의 초미세 다이아몬드가 생성되었음을 확인할 수 있었다. 반면 $\mathrm{Zn}$ 가 코팅되지 않 은 금속촉매를 사용한 경우는 고압인 경우인 $10.7 \mathrm{GPa}$ 을 제외하고 모두 $3 \mu \mathrm{m}$ 급의 초미세 다이아몬드가 제조되었 다. 즉, $38 \mu \mathrm{m}$ 이하의 초미세다이아몬드 분말에 대해 본 결과는 명확히 압력을 작게 하거나 적층형 셀에서 $\mathrm{Zn}$ 를 도금하여 더 작은 다이아몬드를 쉽게 만들 수 있음을 보 이고 있다. 고봉 ${ }^{5)}$ 은 튜브형 셀을 이용하여 $5.6 \mathrm{GPa}$ 압력 조건에서 $\mathrm{Zn}$ 를 분말형태로 혼합시켜 $10 \mu \mathrm{m}$ 크기의 초미 세 다이아몬드를 성공적으로 제조하였다는 보고를 한 바 있으나, 본 연구는 이 보다 상대적으로 단순한 공정으로

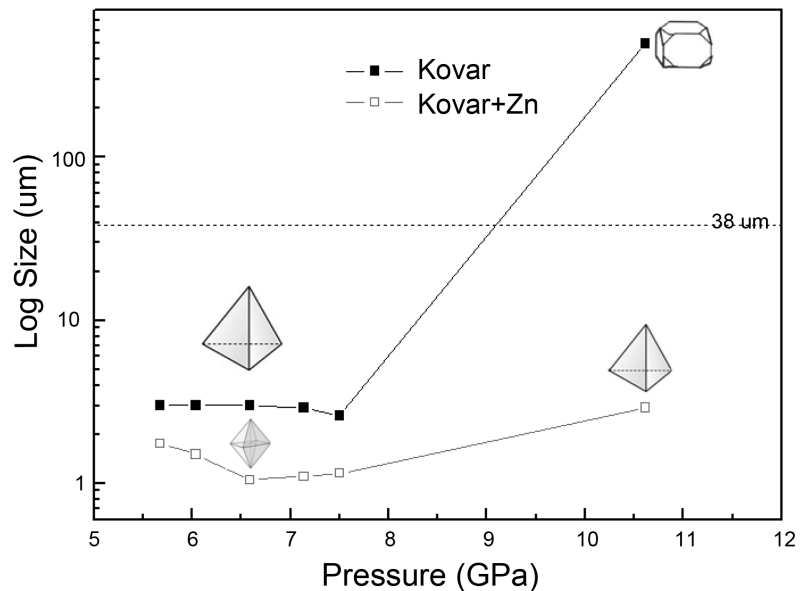

Fig. 5. The plot of the size and shape of the diamonds with pressure.

분말다이아몬드의 크기를 조절할 수 있음을 의미하였다.

한편 대부분의 실험범위에서 사면체 형상의 다이아몬 드가 생성되었고, $10.6 \mathrm{GPa}$ 인 경우의 일반 금속촉매의 경 우로 잘 알려진 바와 같이[100], [111] 성장방향의 안정한 14 면체의 형상이 생성되었고, 이는 고봉 ${ }^{5)}$ 의 보고와 일치 하였다. 반면 $\mathrm{Zn}$ 를 코팅한 금속촉매의 경우는 $6.2 \mathrm{GPa}$ 의 경우에서 8면체 형상이 얻어진 경우 외에는 [111] 성장이 우세한 사면체 형상의 다이아몬드가 생성되었다. 따라서 압력과 $\mathrm{Zn}$ 코팅을 이용해서 다이아몬드의 형상을 균일하 게 조절할 수 있는 가능성을 보였고, 이는 기존에 보고된 튜브형 셀을 이용하는 경우보다 균일한 사면체 형상의 초 미세다이아몬드를 제조하는데 유리하다고 예상되었다.

Fig. 6의 (a)는 5.7, $10.6 \mathrm{GPa}$ 에서 제조된 초미세다이아 몬드와 흑연 혼합 분말의 온도범위 $100 \sim 900^{\circ} \mathrm{C}$ 까지의 열 중량분석(TGA)을 나타낸 결과이다. 혼합분말은 $100^{\circ} \mathrm{C}$ 부 터 $680^{\circ} \mathrm{C}$ 까지 압력의 의존성 없이 안정적으로 중량 변화 가 없다가 $680^{\circ} \mathrm{C}$ 부터 급격히 흑연이 먼저 산화되기 시작 하였다. 이후 $750^{\circ} \mathrm{C}$ 부터는 본격적으로 다이아몬드가 산소 와 결합하며 분해가 진행하는 것으로 판단되었다. 따라서

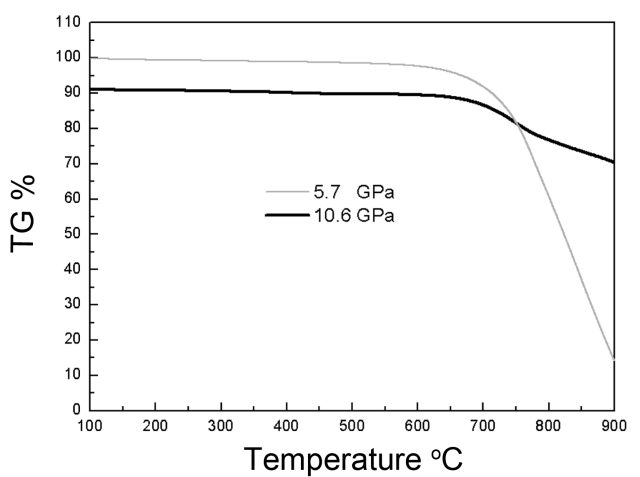

(a)

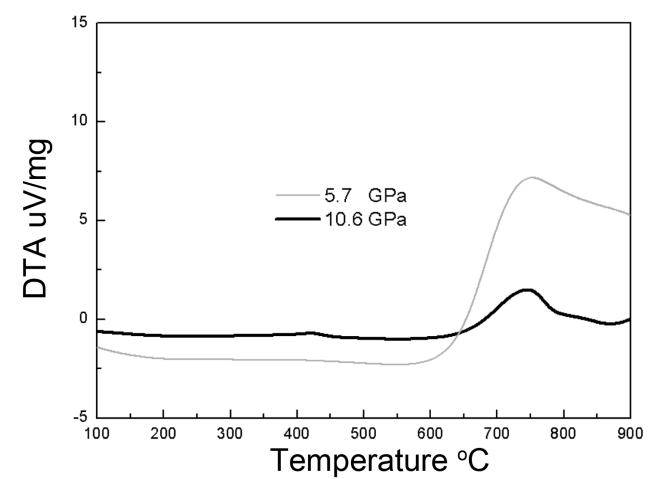

(b)

Fig. 6. The graphs of (a) TGA and (b) DTA of diamond and graphite mixtures HPHT prepared at 5.7 and 10.6 GPa. 


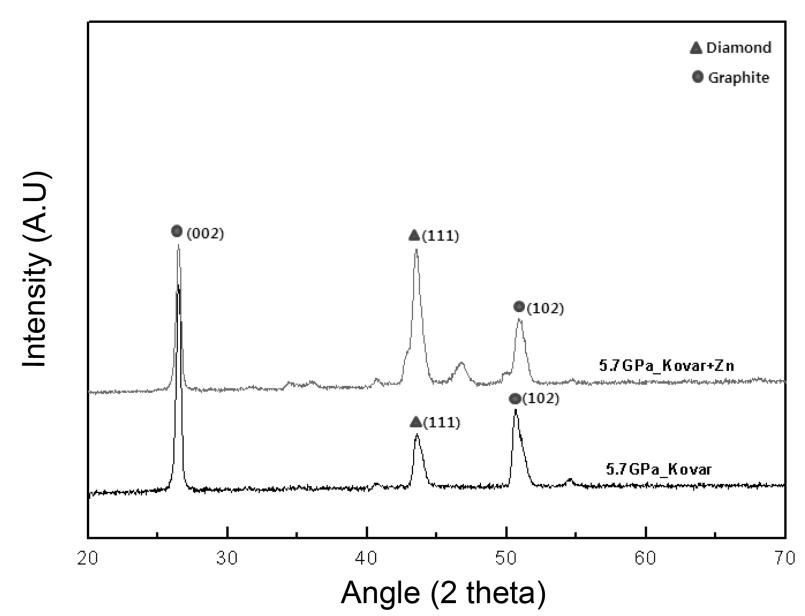

Fig. 7. The HR-XRD curves of diamond and carbon from $\mathrm{NiFeMnCo}$ and $\mathrm{NiFeMnCo}+\mathrm{Zn}$ in $5.7 \mathrm{GPa}$.

선택적으로 흑연을 먼저 제거하기 위해서는 비교적 저온 인 $650^{\circ} \mathrm{C}$ 부근에서 장시간 유지하는 것이 유리하다고 판 단하였다.

(b)는 다이아몬드와 흑연 혼합분말을 시차열분석 DTA(differential thermal analysis)을 진행한 결과를 나타냈 다. (a)의 열중량분석 결과와 동일하게 압력과 관계없이 모두 $750^{\circ} \mathrm{C}$ 에서 에너지가 급격히 증가한 것을 관찰할 수 있었다. 이는 다이아몬드와 흑연 혼합분말이 $750^{\circ} \mathrm{C}$ 부근 에서 산소와 반응하여 이산화탄소로 반응하는 발열반응 을 하였음을 명확히 나타낸다.

Fig. 7은 금속디스크의 표면부를 $\mathrm{XRD}$ 로 분석한 결과이 다. 기존의 금속촉매(Kovar) 디스크와 $\mathrm{Zn}$ 를 도금한 금속 촉매 디스크를 사용한 시료들로, 이때 고온고압 공정조건 으로 온도는 $1500^{\circ} \mathrm{C}$, 공정시간은 $280 \mathrm{sec}$ 로 고정하고 공 정압력은 각각 $5.7 \mathrm{GPa}$ 로 하여 실험을 진행한 시편들의 결과이다.

금속디스크부에 생성된 다이아몬드 피크를 측정한 결 과 $\mathrm{Zn}$ 유무와 관련 없이 모두 그래프에 표시한 $43.8^{\mathrm{O}}(111)^{10-14)}$ 피크가 측정되어 다이아몬드상의 존재를 보 이고 있다. $26.4^{\circ}$ 는 흑연(002) 피크이고 그 외 피크들은 Kovar 합금의 피크들이다. 이러한 다이아몬드 특성피크가 $7.5,10.6 \mathrm{GPa}$ 로 압력이 변화되어도 동일하게 확인되었고, 다른 압력조건의 XRD 분석을 통하여 전체 압력범위에서 $\mathrm{Zn}$ 코팅 유무와 관련 없이 다이아몬드가 생성되었음을 확 인하였다.

Fig. 8은 기존의 금속촉매디스크와 $\mathrm{Zn}$ 를 도금한 금속촉 매디스크를 HPHT 장비를 활용하여 압력을 각각 5.7, 7.5, $10.6 \mathrm{GPa}$ 로 변화하여 생성된 분말형 합성다이아몬드의 마 이크로라만 스펙트럼이다. 그림에서는 모두 고온고압 처 리를 하였을 때 다이아몬드와 그라파이트의 라만 스펙트 럼인 $1332 \mathrm{~cm}^{-1}$ 와 $1600 \mathrm{~cm}^{-1}$ 에서 피크가 생성됨에 근거하 여 ${ }^{15-17)}$ 본 실험조건의 고온고압 공정으로 다이아몬드의

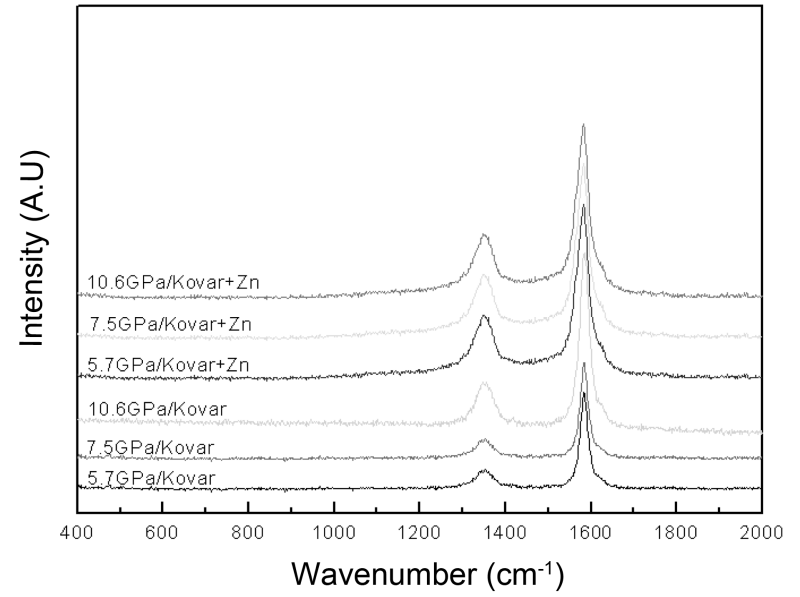

Fig. 8. The raman shift of diamond particles with $\mathrm{Zn}$ coating prepared at 5.7, 7.5 and 10.6 GPa.

생성을 재확인하였다.

\section{4. 결 론}

본 연구에서는 적층형 셀을 사용하여 단순히 기존의 압 력 $10.6 \mathrm{GPa}$ 보다 낮추거나 또는 금속촉매층에 $7 \mu \mathrm{m}$ 의 $\mathrm{Zn}$ 를 도금하여 초미세다이아몬드의 합성을 확인하였다. 합 성된 초미세다이아몬드의 생성은 전자현미경과, $\mathrm{XRD}$, 마 이크로라만분석으로 확인되었다. $\mathrm{Zn}$ 층이 없는 경우는 공 정압력을 $7.5 \mathrm{GPa}$ 이하에서는 $3 \mu \mathrm{m}$ 급의 사면체형상의 초 미세 다이아몬드를, 압력조건 $10.6 \mathrm{GPa}$ 에는 $500 \mu \mathrm{m}$ 의 14 면체의 초미세다이아몬드가 생성된 것을 확인하였다. 반면 $\mathrm{Zn}$ 가 도금된 경우는 전체압력 범위에서 $1.5 \mu \mathrm{m}$ 급 크 기의 사면체 형상의 초미세다이아몬드가 생성되는 것을 확인하였다. 따라서 상대적으로 낮은 압력과 $\mathrm{Zn}$ 를 도금 하는 간단한 신공정으로 초미세다이아몬드의 합성이 가 능함을 확인하였다.

\section{Acknowledgment}

이 논문은 2011년도 일반연구자지원사업의 지원을 받 아 수행된 것임(2011-006629).

\section{REFERENCES}

1. W. Tillmann, "Trends and Market Perspectives for Diamond Tools in the Construction Industry," Int. J. Refract. Met. Hard Mater, 18 301-6 (2000).

2. S. P. Hegde and J. B. McDermott, "The Market Liquidity of Diamonds, Q's, and Their Underlying Stocks," J. Bank. Finance, 28 1043-67 (2004).

3. M. Akaishi, H. Kanda, and S. Yamaoka, "High Pressure Synthesis of Diamond in the Systems of Grahpite-Sulfate and Graphite-Hydroxide," J. Appl. Phys., 29 1172-74 (1990). 
4. H. Sumiya and S. Satoh, "High-Pressure Synthesis of HighPurity Diamond Crystal," Int. J. Refract. Met. Hard Mater. 17 1359-65 (1996).

5. F. Gao, "The Synthesis of High Quality Diamond with Supper-fine Grain Size," pp. 1-98, Ph.D. Thesis, Jilin University, Jilin, 2008.

6. L. Pan, T. J. Peng, and J. M. Chen, "Research in Fine Diamond Separation," Non Metallic Mines, 27 33-4 (2007).

7. R. Z. Yu, "Synthesis of High Nitrogen Concentration Industrial Diamond By High Temperature High Pressure," pp. 162, Master Thesis, Jilin University, Jilin, 2005.

8. S. Ganesan, A. A. Maradudin, and J. Oitmaa, "A Lattice Theory of Morphic Effects in Crystals of the Diamond Structure," Ann Phys., 56 [2] 556-94 (1970).

9. M. H. Grimsditch, E. Anastassakis, and M. Cardona, "Effect of Uniaxial Stress on the Zone-Center Optical Phonon of Diamond," Phys. Rev. B., 18 [2] 901-4 (1978).

10. H. Pang, X. Q. Wang, G. L. Zhang, H. Chen, G. H. Lv, and S. Z. Yang, "Characterization of Diamond-like Carbon Films by SEM, XRD and Raman Spectroscopy," Surface Science, 256 6403-07 (2010).

11. Y. Reynier, R. Yazami, and B. Fultz, "XRD Evidence of Macroscopic Composition Inhomogeneities in the Graphite- lithium Electrode," J. Power Sources, 165 616-9 (2007).

12. T. Arunagiri, T. D. Golden, and O. Chyan, "Study of Palladium Metal Particles Deposition on the Conductive Diamond Surface by XRD, XPS and Electrochemistry," Mater. Chem. and Phys., 92 152-8 (2005).

13. G. Y. Lee and J. H. Je, "Chemical Vaper Deposition of Diamond Film from Methane-Hydrogen Gas in Microwave Plasma," J. Kor. Ceram. Soc., 26 [3] 331-40 (1989).

14. E. V. Golubina, S. A. Kachevsky, E. S. Lokteva, V. V. Lunin, P. Canton, and P. Tundo, "TEM and XRD Investigation of Pd on Ultradispersed Diamond, Correlation with Catalytic Activity," Mendeleev Communicati Ons, 19 133-5 (2009).

15. S. Piscanec, F. Mauri, A .C. Ferrari, M. Lazzeri, and J. Robertson, "Ab Initio Resonant Raman Spectra of Diamond-like Carbons," Diamond and Related Mater., 14 1078-83 (2005).

16. L. Yu. Khriachtchev, R. Lappalainen, M. Hakovirta, and M. Rsnen, "Raman Diagnostics of Amorphous Diamond-like Carbon Films Produced with a Mass-separated Ion Beam," Diamond and Related Mater., 6 694-9 (1997).

17. C. Casiraghi, "Effect of Hydrogen on the UV Raman Intensities of Diamond-like Carbon," Diamond and Related Mater, 20 120-2 (2011). 